Article

\title{
Health Surveillance of Wild Brown Trout (Salmo trutta fario) in the Czech Republic Revealed a Coexistence of Proliferative Kidney Disease and Piscine Orthoreovirus-3 Infection
}

\author{
L'ubomír Pojezdal ${ }^{1, *}$, Mikolaj Adamek ${ }^{2}$, Eva Syrová ${ }^{1,3}$, Dieter Steinhagen ${ }^{2}{ }^{\oplus}$, \\ Hana Minářová ${ }^{3,4}$, Ivana Papežíková ${ }^{3,5}$, Veronika Seidlová ${ }^{3}$, Stanislava Reschová ${ }^{1}$ \\ and Miroslava Palíková 3,5 \\ 1 Department of Virology, Veterinary Research Institute, 62100 Brno, Czech Republic; syrova@vri.cz (E.S.); \\ reschova@vri.cz (S.R.) \\ 2 Fish Disease Research Unit, Institute for Parasitology, University of Veterinary Medicine, \\ 30559 Hannover, Germany; mikolaj.adamek@tiho-hannover.de (M.A.); \\ Dieter.Steinhagen@tiho-hannover.de (D.S.) \\ 3 Department of Ecology and Diseases of Zooanimals, Game, Fish and Bees, Veterinary and Pharmaceutical \\ University, 61242 Brno, Czech Republic; minarova@vri.cz (H.M.); papezikovai@vfu.cz (I.P.); \\ seidlovav@vfu.cz (V.S.); palikovam@vfu.cz (M.P.) \\ 4 Department of Immunology, Veterinary Research Institute, 62100 Brno, Czech Republic \\ 5 Department of Zoology, Fisheries, Hydrobiology and Apiculture, Mendel University, \\ 61300 Brno, Czech Republic \\ * Correspondence: pojezdal@vri.cz
}

Received: 30 June 2020; Accepted: 21 July 2020; Published: 24 July 2020

check for

\begin{abstract}
The population of brown trout (Salmo trutta fario) in continental Europe is on the decline, with infectious diseases confirmed as one of the causative factors. However, no data on the epizootiological situation of wild fish in the Czech Republic are currently available. In this study, brown trout $(n=260)$ from eight rivers were examined for the presence of viral and parasitical pathogens. Salmonid alphavirus-2, infectious pancreatic necrosis virus, piscine novirhabdovirus (VHSV) and salmonid novirhabdovirus (IHNV) were not detected using PCR. Cell culturing showed no viruses as well, and serological analysis of 110 sera did not detect any specific antibodies against VHSV or IHNV. Fish from two rivers were positive for the presence of piscine orthoreovirus-3 (PRV-3), subtype PRV-3b. However, none of the PRV-3-positive fish showed gross pathologies typically associated with PRV infections. By far the most widespread pathogen was Tetracapsuloides bryosalmonae which was confirmed in each of the examined locations, with a prevalence of up to $65 \%$ and $100 \%$, as established by immunohistochemistry and PCR, respectively. Furthermore, up to $43.8 \%$ of fish showed signs of proliferative kidney disease caused by T. bryosalmonae, suggesting that this parasite is a main health challenge for brown trout in the Czech Republic.
\end{abstract}

Keywords: immunohistochemistry; infectious hematopoietic necrosis; infectious pancreatic necrosis; PCR; salmonid alphavirus; serology; Tetracapsuloides bryosalmonae; viral hemorrhagic septicemia

\section{Introduction}

The number of recirculation and flow-through systems rearing portion-sized salmonids, mostly rainbow trout (Oncorhynchus mykiss) and brook trout (Salvelinus fontinalis), in the Czech Republic is slowly but steadily increasing, with 1.1 tons of fish produced in 2018 [1]. Infectious diseases, especially those listed by OIE [2], pose an economic threat to aquaculture either directly, via clinical 
signs, lower weight gain and higher mortality [3], or indirectly, via the costs of surveillance, prevention and eradication measures, which are mandated by European and national legislation. Considering the OIE-listed diseases of viral origin, the Czech Republic is declared free of infectious salmon anemia (ISA), but has a non-defined status considering viral hemorrhagic septicemia (VHS) and infectious hematopoietic necrosis (IHN), with outbreaks of both diseases occurring sporadically throughout the years [4]. The unusually high number of outbreaks of VHS and IHN in the winter of 2013/2014 [5], followed by costly eradication measures, raised the question of the role of wild fish as possible pathogen vectors in the environment of Czech rivers.

Several pathogens are considered a threat to wild salmonids in continental Europe. Piscine novirhabdovirus (formerly viral hemorrhagic septicemia virus, VHSV) remains the greatest problem. This virus was proven to infect wild and feral salmonids in European waters, most notably in direct connection with an active outbreak site in the vicinity [6], but VHSV was also identified in asymptomatic animals, such as European river lamprey (Lampetra fluviatilis) in Finland [7], or wild salmonids in Swiss rivers [8]. VHSV was also present in multiple wild saltwater species $[9,10]$ and genotype IV of the virus caused massive multi-species mortality events in the North American Great Lakes in the early 2000s [11,12]. Salmonid novirhabdovirus (previously infectious hematopoietic necrosis virus, IHNV) is endemic in the Northwest Pacific off the coast of North America [13]. The presence of the virus in European wild fishes was mostly reported as asymptomatic, such as the findings in brown trout (Salmo trutta fario) in the Republic of Kosovo [14] and in Switzerland [8], or in pike (Esox lucius) in France [15].

Further pathogens seem to emerge as potential novel threats. Clinical infection caused by Piscine orthoreovirus-3 (PRV-3) in rainbow trout was first described in Norway in 2013 [16], associated with anemia, heart and skeletal muscle inflammation and liver necrosis. Experimental infection with purified PRV-3 particles was recently proven to cause heart inflammation in rainbow trout [17]. The presence of the virus was confirmed in farmed rainbow trout in Germany [18], Italy and Denmark [19], in coho salmon (Oncorhynchus kisutch) in Chile [20] and in wild brown trout in Germany [21]. Kuehn et al. [21] argued that the virus is the main causative agent of the proliferative darkening syndrome (PDS), a disease affecting wild brown trout populations in pre-alpine rivers in Switzerland, Germany and Austria. PDS manifests itself with pathoanatomical signs such as skin darkening, hemorrhages and necrosis of liver, spleen and kidney resulting in massive species-specific die-offs of brown trout during the late summer months [22]. On the contrary, the presence of PRV-3 was described in clinically healthy brown trout [23], and brown trout showing PDS signs also tested PRV-3-negative in other cases [24]. Arndt et al. [24] connected the mortalities of brown trout in Austrian rivers with proliferative kidney disease (PKD), caused by the myxozoan Tetracapsuloides bryosalmonae. Additionally, Lewisch et al. [25] confirmed the presence of the parasite in wild fish from the majority of examined Austrian rivers, along with the clinical and pathoanatomical signs typical for PKD, such as darkened skin, abdominal distention and enlargement of the kidney and spleen [26].

With T. bryosalmonae recently confirmed as a pathogen of rainbow trout in one of the Czech recirculation aquaculture systems [27], and VHS and IHN outbreaks occasionally occurring in farmed animals in the country [4], we decided to evaluate the epizootiological situation of wild salmonids. The populations of these fish have been declining in the last decades and the presence of the selected pathogens has never been evaluated and remained unknown before the publication of this study. Furthermore, for the first time, we report the presence of the piscine orthoreovirus-3 and T. bryosalmonae coinfection in the Czech Republic's brown trout population and explore the potential role of wild salmonids as vectors of the aforementioned pathogens. 


\section{Results}

\subsection{Sampled Fish, Gross Pathology}

In total, 266 salmonids were collected, mostly brown trout $(\mathrm{n}=260)$ along with rainbow trout $(\mathrm{n}=5)$ and brook trout $(\mathrm{n}=1)$. The average weight of the fish was $67 \mathrm{~g}(\mathrm{SD} \pm 45.1 \mathrm{~g})$ with the average total lenght of $173 \mathrm{~mm}(\mathrm{SD} \pm 51.9 \mathrm{~mm})$. Most prevalent macroscopic lesions comprised swollen kidney $(n=36$, Table 2$)$ followed by enlarged spleen $(n=3)$, pale liver $(n=2)$ and saprolegniosis of adipose and caudal fins $(n=2)$. The presence of up to three leeches (Piscicola spp.) was noted on the fins of four fish from one location (Loučka, CZ-2082).

\subsection{Serological Examination}

In total, 110 sera were examined for the presence of specific antibodies against VHSV and IHNV using enzyme-linked immunosorbent assays (ELISA). In all samples, the pure absorbance value did not cross the threshold of 0.100 (Table 1). Therefore, all samples were declared negative for the presence of each of the two virus-specific antibodies. The titer of positive hyperimmune sera showed the values of 1:12,800 for VHSV and 1:6400 for IHNV and the average absorbance of a serum in 1:100 dilution analyzed on a negative antigen was determined as $0.150(\mathrm{SD} \pm 0.034)$ for VSHV and $0.149(\mathrm{SD} \pm 0.036)$ for IHNV.

Table 1. Results of the virological analysis of the samples.

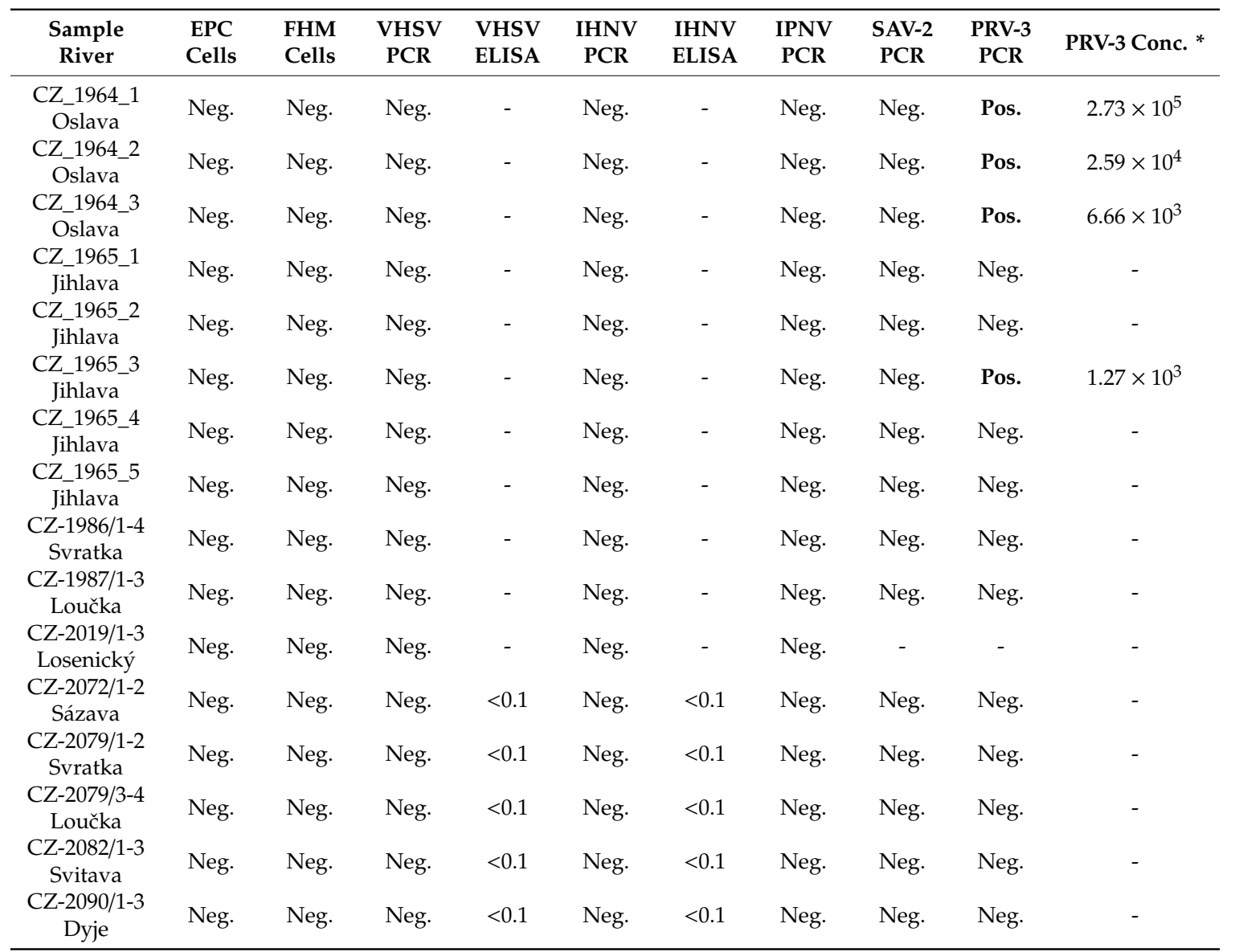

${ }^{*}$ Quantification via plasmid-based standard curve with normalization of the target RNA copies with 10,000 copies of trout elongation factor $1 \alpha$; EPC: cultivation on the epithelioma papulosum cyprini cell line, FHM: cultivation on the fathead minnow cell line. 


\subsection{Virological Examination}

Virus isolation from 33 pooled samples containing material from a total of 266 fish showed no cytopathic effect on the fathead minnow (FHM) and epithelioma papulosum cyprini (EPC) cell lines after two rounds of a seven-day cultivation. The samples were therefore declared free of cultivable viral pathogens.

PCR assays targeting VHSV, IHNV, IPNV and SAV-2 showed negative results for each pooled sample tested. The conventional PCR for the detection of PRV-3 showed the presence of the virus in four of the analyzed samples (Table 1). Three samples from the location CZ-2019/1-3 were not tested for SAV-2 and PRV-3 due to material degradation during long-term storage.

All samples were sequenced and the 371 bp sequences were analyzed phylogenetically with the corresponding PRV-3 sequences available in the GenBank database (Figure 1).

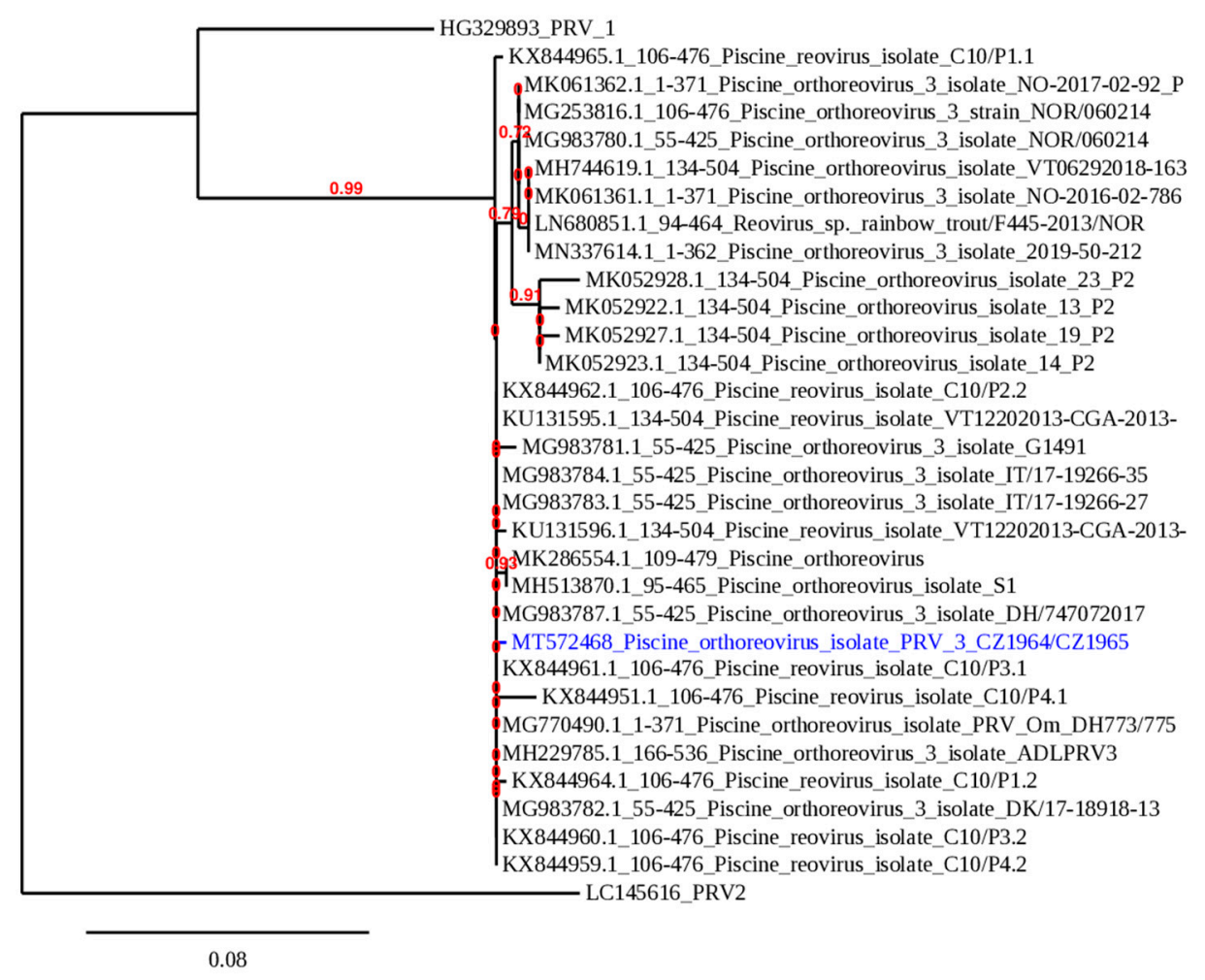

Figure 1. Phylogenetic analysis of PRV-3 isolates. A maximum likelihood phylogenetic analysis performed with PhyML on the 371 bp nucleotide sequence encoding a fragment of the segment S1 of the sigma 3 protein of the PRV-3 isolate from Czechia (GenBank ID: MT572468) which is marked in blue and other PRV-3 isolates available in GenBank. The branch length is proportional to the number of substitutions per site. The branch supporting values are indicated in red.

All Czech isolates possessed the same sequence (GenBank ID: MT572468). Interestingly, the obtained sequence is a unique member of the PRV-3b subtype, with a very high level of identity $(99.73 \%)$ to the sequences from several isolates from Germany, Italy, Denmark but also Chile. The real-time PCR assay for PRV-3 confirmed the presence of the virus in four respective samples and the number of copies of the target gene was calculated (Table 1). The normalized virus load was high, measuring from $1.27 \times 10^{3}$ copies to $2.73 \times 10^{5}$ copies.

\subsection{Parasitological Examination}

The results of the parasitological examination provided in Table 2 indicate that the parasite T. bryosalmonae was present in a varying percentage of fish at every location, even in the samples where the prevalence of gross renal lesions reached $0 \%$. 
Table 2. Results of the parasitological examination focused on Tetracapsuloides bryosalmonae.

\begin{tabular}{|c|c|c|c|c|}
\hline $\begin{array}{l}\text { Sample } \\
\text { River }\end{array}$ & Fish (n) & $\begin{array}{l}\text { Swollen Kidney } \\
(\%)\end{array}$ & $\begin{array}{c}\text { IHC Positive Fish (\%) } \\
\text { Parasites }(n) *(\text { Mean } \pm \text { SD) }\end{array}$ & $\begin{array}{l}\text { qPCR Positive } \\
\text { Fish }(\%) * * \\
\text { Mean Ct } \pm \text { SD }\end{array}$ \\
\hline CZ-1964 & \multirow{2}{*}{32} & \multirow{2}{*}{3.1} & 15.6 & $96.9^{* * *}$ \\
\hline Oslava & & & $0.68 \pm 0.70$ & $28.08 \pm 2.77$ \\
\hline CZ-1965 & \multirow{2}{*}{28} & \multirow{2}{*}{7.1} & 14.3 & $100.0 * * *$ \\
\hline Jihlava & & & $3.45 \pm 3.14$ & $24.50 \pm 1.63$ \\
\hline CZ-1986 & \multirow{2}{*}{32} & \multirow{2}{*}{0} & 9.4 & $25.0 * * *$ \\
\hline Svratka & & & $0.50 \pm 0.32$ & $31.73 \pm 1.13$ \\
\hline CZ-1987 & \multirow{2}{*}{30} & \multirow{2}{*}{0} & 10.0 & $73.3^{* * *}$ \\
\hline Loučka & & & $0.80 \pm 1.04$ & $27.07 \pm 3.14$ \\
\hline CZ-2019 & \multirow{2}{*}{32} & \multirow{2}{*}{43.8} & 62.5 & $6.3^{* * *}$ \\
\hline Losenický & & & $24.02 \pm 22.63$ & $31.0 \pm 0,84$ \\
\hline CZ-2072 & \multirow{2}{*}{17} & \multirow{2}{*}{17.6} & 35.3 & $94.1^{* * * *}$ \\
\hline Sázava & & & $8.60 \pm 8.88$ & $23.98 \pm 3.26$ \\
\hline CZ-2079/1,2 & \multirow{2}{*}{16} & \multirow{2}{*}{18.8} & 50.0 & $81.3^{* * * *}$ \\
\hline Svratka & & & $3.39 \pm 3.39$ & $26.77 \pm 2.81$ \\
\hline CZ-2079/3,4 & \multirow{2}{*}{17} & \multirow{2}{*}{17.6} & 64.7 & $76.5^{* * * *}$ \\
\hline Loučka & & & $24.54 \pm 59.75$ & $28.54 \pm 3.28$ \\
\hline CZ-2082 & \multirow{2}{*}{30} & \multirow{2}{*}{0} & 6.7 & $56.7^{* * * *}$ \\
\hline Svitava & & & $1.40 \pm 1.84$ & $29.85 \pm 2.39$ \\
\hline CZ-2090 & \multirow{2}{*}{32} & \multirow{2}{*}{21.9} & 21.9 & $59.4^{* * * *}$ \\
\hline Dyje & & & $3.96 \pm 6.13$ & $27.91 \pm 2.57$ \\
\hline
\end{tabular}

* The average number of parasites in the field of view, magnification $200 \times, 10$ fields per slide, ${ }^{* *}$ detection limit: $\mathrm{Ct}$ 32 (inclusive), ${ }^{* * *}$ DNA extracted from formalin-fixed, paraffin wax-embedded kidney tissue, ${ }^{* * * *}$ DNA extracted from $70 \%$ ethanol-fixed kidney tissue; IHC: immunohistochemistry, SD: standard deviation.

\section{Discussion}

The original aim of this study was to analyze the possible presence of viral pathogens, especially the ones causing notifiable diseases, in Czech rivers. The assays for the detection of piscine orthoreovirus-3 were added after multiple reports of the presence of the virus in European freshwater salmonids. Finally, the methods for the detection of T. bryosalmonae were included due to pathomorphological signs present in a large portion of the examined fish.

\subsection{Viral Pathogens}

The rivers selected for this study had various levels of connection to the farms rearing susceptible salmonids with a history of VHS or IHN outbreaks. None of the sites were tested during an active outbreak on any of the watersheds, due to practical reasons and to comply with the recommended water temperatures for VHSV/IHNV sampling events [28]. The delay between the last recorded outbreak and the first sampling was at least six months, which could have lowered the chances for the detection of the viruses. Even though VHSV and IHNV have historically been detected in European freshwater salmonids [8,14] and both viruses are causing occasional outbreak events in Czech fish farms [4], this study failed to prove the presence of the pathogens in the sampled brown trout specimens.

The lesser distribution of the viral pathogens in wild and feral fish compared with the fish reared in aquaculture establishments could have biological reasons, such as the lower susceptibility of brown trout to the viral infection [29], or environmental reasons, namely the lower population density and stress levels in wild fish compared with the farmed animals. Additionally, phylogenetic studies of the viral pathogens originating from various outbreak sites repeatedly showed that the transport of live fish and fish eggs is the main factor of the disease distribution amongst individual fish farms [3,30].

This study employed a range of sensitive methods for the detection of the virus capable of replication (cell culture), of viral nucleic acids (PCR) and of specific antibodies against VHSV and IHNV (ELISA). The negative results strongly suggested that the sampled animals were not infected with a notifiable disease-causing virus at the time of sampling and were not exposed to the viruses 
in concentrations causing a lasting antibody response [31,32]. However, the possibility of finding a viral pathogen at the examined locations still cannot be ruled out completely and could be improved, for example, via sampling of a larger number of fish or via repeated sampling in one location. Additionally, the pooling of the samples for the virological examination (deployed due to cost reasons), while still considering the manuals in European legislation for the surveillance of viral pathogens of fish [28], could have lowered the sensitivity of the assays.

As for the non-listed viral diseases, the presence of salmonid alphavirus has never been confirmed in Czech aquaculture, but its prevalence in European countries with rainbow trout production suggests the possibility of its spread via the trade of fish or eggs [33]. Mandatory monitoring of trout farms for the presence of infectious pancreatic necrosis virus was ongoing in the Czech Republic from 2008 to 2011, with zero cases reported positive [34]. The Czech National Reference Laboratory for Viral Diseases of Fish has registered only one isolate of the virus of Czech origin since 1997 (CAPM V-513), but the possibility of the presence of the virus in Czech rivers and aquaculture is still real and cannot be ruled out due to a lack of available data [8].

\subsection{Piscine Orthoreovirus-3}

None of the clinical and pathoanatomical signs corresponding to typical PRV-3 infection in rainbow trout, such as anemia, heart and skeletal muscle inflammation and liver necrosis [17] were observed in the fish examined in this study. However, the PRV-3 infection in sea trout (Salmo trutta trutta) mainly manifests as mild heart inflammation [35] which cannot be evaluated by gross pathology alone and would require a histopathological examination. This assessment should be added in future studies of PRV infections. Additionally, research on the direct influence of purified PRV-3 on the health status of brown trout would be of great importance, along with the potential role of this virus as a cofactor of brown trout disease.

Since the role of PRV-3 as a pathogen of farmed rainbow trout has been established [17], it is necessary to evaluate the possible role of wild salmonids as vectors of the virus between potentially vulnerable rainbow trout farms. Infection experiments on Atlantic salmon and rainbow trout showed variations in PRV-3 sensitivity [36]; an infection trial comparing the susceptibility of rainbow trout and brown trout is therefore to be recommended. The rainbow and brook trout specimens collected in this study were probably escaped animals from a nearby aquaculture establishment because no population of these species was intentionally kept in the examined river (Moravian Fishing Association, personal communication), but the sample size (one and five specimens, respectively) was too small to draw any conclusions regarding the susceptibility of various salmonid species to this specific isolate of the virus.

Mortality events of a scale corresponding to the proliferative darkening syndrome description in the pre-alpine region have never been observed in the rivers represented in this study (Moravian Fishing Association, personal communication). Additionally, no clinical and pathoanatomical signs typical for PDS, such as darkening of the skin, anemia and liver necrosis, were observed in the examined fish, even in the rivers positive for PRV-3. It is, however, possible that the cases presented in this publication did not manifest clinical signs of infection due to the season, when the water temperature was not providing the best conditions for PDS development [21] or the environment of the Czech rivers was not suitable for PDS development. Further research of the possible relationship between PRV-3 and PDS is required $[23,24]$.

\subsection{Proliferative Kidney Disease}

All pathoanatomical changes in moribund fish examined in this study corresponded to the typical proliferative kidney disease signs [26], but a possible role of coinfection cannot be ruled out completely because the PRV-3-positive fish were also positive for T. bryosalmonae. A potentiating effect of T. bryosalmonae and a viral agent (VHSV) on the changes of the immune system of salmonids was previously described by Gorgoglione et al. [37]. Other studies confirmed that a Raphidascaris acus infection prolonged PKD-related gross changes in brown trout kidneys [38]. 
The first cases of proliferative kidney disease in Czech aquaculture were reported during the 1980s [39], but no targeted surveillance of the distribution of this parasite in Czech wild salmonids has ever been conducted, despite the growing evidence of adverse effects of the infection on the brown trout populations in neighboring countries [24,25]. This study shows a widespread presence of the parasite in Czech rivers because at least some of the fish from all eight locations were tested positive for the presence of T. bryosalmonae in the kidney tissue during ten separate sampling events. This prevalence was confirmed by both diagnostic methods (IHC and qPCR) used, with the immunohistochemistry method showing significantly lower percentages of positive fish from each location compared with the results obtained by real-time PCR, which is a finding consistent with other published studies employing both methods of parasite detection [24,40]. This finding puts previous studies relying on histopathology or IHC for the confirmation of T. bryosalmonae infection in perspective and suggests that the percentages of positive samples, significant as they are, could be even higher when utilizing molecular techniques.

Using histopathology and IHC, the PKD situation was best mapped in Switzerland, where T. bryosalmonae was found in $40-50 \%$ of the sampled rivers [41-43]. Studies on brown trout were also conducted in England (86\% of rivers [44]) and Estonia (around 50\% of rivers [45]). A recent study showed the presence of the parasite in $81 \%$ of the sampled rivers in Austria using conventional PCR [25]. In this study, the only two repeatedly sampled locations showed higher percentages of the examined fish displaying pathomorphological signs of PKD, along with greater numbers of samples tested positive for the presence of T. bryosalmonae using both IHC and qPCR in November, compared with the situation in April. Although the temperature in every sampling campaign presented was not optimal for the propagation of the parasite [43], the data confirmed the observed cycle of the infection in brown trout, with infection rates and pathoanatomical changes peaking in late summer [24], and a significant decline during cold temperature periods $[25,27]$ when a partial or complete regeneration of renal tissue occurs [38]. To establish whether the reoccurring PKD symptoms in specific rivers are caused by reinfection of susceptible animals [38] or by a persistence of the parasite in clinically healthy fish $[46,47]$ was beyond the scope of this study and would require additional repeated testing of selected locations.

T. bryosalmonae acts as an immunomodulant [48] and can potentially cause up to $20 \%$ mortality in affected brown trout [26], with additional coinfections potentiating the pathologic effects [37,38]. Additionally, infections of European brown trout have a larger impact on the health of the infected fish, when compared with rainbow trout $[40,49]$. Despite the ubiquitous presence of the parasite in wild brown trout from Czech rivers, the local decline of the species cannot be blamed solely on this pathogen. However, additional factors contributing to the loss of fish [50], such as water pollution [51], river eutrophication [52] and a rising water temperature [53] also create suitable conditions for a better propagation of the pathogen.

To our knowledge, this study presents the first detection of piscine orthoreovirus-3 in the Czech Republic and also represents the first described cases of proliferative kidney disease of wild brown trout from the Czech Republic.

\section{Materials and Methods}

\subsection{Sample Collection and Preparation}

Salmonid populations from eight Czech rivers with various connections to former VHS or IHN outbreak sites were sampled during ten separate sampling events in 2015-2017 in the season when the water temperatures did not exceed $14^{\circ} \mathrm{C}$, in accordance with European Legislation [28]. At each location, from 16 up to 32 specimens of brown trout and any additional salmonid species present were caught by electric fishing, with a total number of 266 fish (Table 3). The fish were measured and weighed on the spot and delivered alive to the laboratory. 
Table 3. Sites, dates and animals sampled for this study.

\begin{tabular}{|c|c|c|c|c|c|c|c|}
\hline Sample & River & Date & GPS & $S T$ (n) & Other (n) & Temp. $\left({ }^{\circ} \mathrm{C}\right)$ & Sera $(n)$ \\
\hline CZ-1964/1-5 & Oslava & 27 October 2015 & $\begin{array}{l}49^{\circ} 21^{\prime} 59.0^{\prime \prime} \mathrm{N} \\
16^{\circ} 01^{\prime} 06.1^{\prime \prime} \mathrm{E}\end{array}$ & 26 & $O M 1, S F 5$ & 4.0 & - \\
\hline CZ-1965/1-3 & Jihlava & 28 October 2015 & $\begin{array}{l}49^{\circ} 05^{\prime} 52.8^{\prime \prime} \mathrm{N} \\
16^{\circ} 13^{\prime} 18.2^{\prime \prime} \mathrm{E}\end{array}$ & 28 & - & 11.0 & - \\
\hline CZ-1986/1-4 & Svratka & 18 April 2016 & $\begin{array}{l}49^{\circ} 28^{\prime} 59.5^{\prime \prime} \mathrm{N} \\
16^{\circ} 20^{\prime} 22.7^{\prime \prime} \mathrm{E}\end{array}$ & 32 & - & 6.8 & - \\
\hline CZ-1987/1-3 & Loučka & 18 April 2016 & $\begin{array}{l}49^{\circ} 23^{\prime} 25.0^{\prime \prime} \mathrm{N} \\
16^{\circ} 18^{\prime} 08.2^{\prime \prime} \mathrm{E}\end{array}$ & 30 & - & 9.9 & - \\
\hline CZ-2019/1-3 & Losenický & 26 October 2016 & $\begin{array}{l}49^{\circ} 34^{\prime} 06.9^{\prime \prime} \mathrm{N} \\
15^{\circ} 46^{\prime} 27.0^{\prime \prime} \mathrm{E}\end{array}$ & 32 & - & 9.0 & - \\
\hline CZ-2072/1-2 & Sázava & 25 September 2017 & $\begin{array}{l}49^{\circ} 33^{\prime} 16.2^{\prime \prime} \mathrm{N} \\
15^{\circ} 50^{\prime} 55.4^{\prime \prime} \mathrm{E}\end{array}$ & 17 & - & 12.8 & 15 \\
\hline CZ-2079/1-2 & Svratka & 2 October 2017 & $\begin{array}{l}49^{\circ} 28^{\prime} 59.5^{\prime \prime} \mathrm{N} \\
16^{\circ} 20^{\prime} 22.7^{\prime \prime} \mathrm{E}\end{array}$ & 16 & - & 7.7 & 16 \\
\hline CZ-2079/3-4 & Loučka & 2 October 2017 & $\begin{array}{l}49^{\circ} 23^{\prime} 25.0^{\prime \prime} \mathrm{N} \\
16^{\circ} 18^{\prime} 08.2^{\prime \prime} \mathrm{E}\end{array}$ & 17 & - & 7.1 & 17 \\
\hline CZ-2082/1-3 & Svitava & 8 November 2017 & $\begin{array}{l}49.2959953 \mathrm{~N} \\
16.6644897 \mathrm{E}\end{array}$ & 30 & - & 7.5 & 30 \\
\hline CZ-2090/1-3 & Dyje & 8 November 2017 & $\begin{array}{l}48.8523892 \mathrm{~N} \\
15.8646003 \mathrm{E}\end{array}$ & 32 & - & 3.3 & 32 \\
\hline
\end{tabular}

ST: Salmo trutta fario, OM: Oncorhynchus mykiss, SF: Salvelinus fontinalis.

The specimens were examined for the presence of clinical and pathoanatomical signs of disease, with an emphasis on changes of the kidneys. After blood samples were collected, the fish were stunned by a blow to the back of the head and killed by a spinal transection. During autopsy, spleen, heart and cranial kidney tissue samples were immediately homogenized for the virological examination and a caudal kidney sample from each fish was fixed for an immunohistochemical examination.

\subsection{Serological Examination}

Blood serum was collected from fish caught in the 5 rivers sampled in 2017. The serum of each individual fish was tested for the presence of specific antibodies against VHSV and IHNV by two separate enzyme-linked immunosorbent assays prepared in house according to Cinkova et al. [54]. The hyperimmune sera and concentrated antigens required for ELISAs were prepared from a recent Czech isolate of each virus and the isolates were also submitted to the Collection of Animal Pathogenic Microorganisms, Veterinary Research Institute, Brno, Czech Republic, under the numbers CAPM V-684 (VHSV) and CAPM V-629 (IHNV). The key reagents of the ELISAs were a conjugate of horseradish peroxidase with rabbit anti-trout antibodies prepared using the periodate method [55] and a chromogenic substrate containing 3.3' 5.5' $^{\prime}$-tetramethylbenzidine (TMB2, TestLine Clinical Diagnostics, Brno, Czech Republic). Absorbance values were measured at a wavelength of $450 \mathrm{~nm}$ using the spectrophotometer SLT Spektra (Schoeller, Sevelen, Switzerland) and pure absorbance was calculated as the difference between the absorbance values of a positive and a negative antigen.

\subsection{Virological Examination}

Spleen, heart and cranial kidney tissues from up to 12 animals were pooled for a total of 33 pooled samples. The tissues were mechanically lysed, suspended in a ten-fold volume of Minimal Essential Medium with Eagles salts MEM HEPES Modification (Sigma-Aldrich, St. Louis, MO, USA) cell culture medium and centrifuged at $3000 \mathrm{G}$ for $14 \mathrm{~min}$ at $4{ }^{\circ} \mathrm{C}$. The supernatant from homogenized pooled tissue samples was incubated overnight at $4{ }^{\circ} \mathrm{C}$ in a 10:1 ratio with Penicillin-Streptomycin Solution 100X (Biosera, Boussens, France) and then incubated in a 24-well open system on two different cell lines-fathead minnow (FHM) and epithelioma papulosum cyprini (EPC) (Sigma-Aldrich, St. Louis, MO, USA) at $15^{\circ} \mathrm{C}$ for 7 days using the Minimal Essential Medium with Eagles salts MEM HEPES Modification medium with 10\% addition of fetal bovine serum (Biochrom, Berlin, Germany) and L-Glutamine $200 \mathrm{mM}$ (Lonza, Basel, Switzerland). The inoculated cell line was $24 \mathrm{~h}$ old at the moment 
of infection and the presence of an intact monolayer was confirmed in each well before the experiment. Material from the first passage was incubated under the same conditions for an additional 7 days.

All samples were examined for the presence of viral pathogens of salmonids using conventional and real-time PCR. The list of specific assays used for each pathogen is shown in Table 4. For nucleic acid extraction, the QIAamp Viral RNA Mini Kit (Qiagen, Hilden, Germany) was used. All samples positive in conventional PCR were prepared for Sanger sequencing performed by LGC Genomics (Berlin, Germany). The obtained nucleotide sequences of the PRV-3 segment S1 were aligned with piscine orthoreovirus sequences available in GenBank using tools available at www.phylogeny.fr [56]. Sequences were aligned with MUSCLE and curated with Gblocks. A maximum likelihood phylogenetic analysis was performed with PhyML and the phylogenetic tree was rendered with TreeDyn. One PRV-1 isolate from Norway (GenBank ID: HG329893) was used for comparison, and the tree was rooted using a PRV-2 sequence (GenBank ID: LC145616) as an outgroup (Figure 1). The approximate viral load was measured in all positive samples by quantitative PCR. The quantification was performed using the plasmid-based standard curve method with normalization of the target RNA copies with 10,000 copies of trout elongation factor $1 \alpha$ [57].

Table 4. PCR assays used in this study.

\begin{tabular}{ccc}
\hline Target Organism & Method & Author \\
\hline VHSV & Real-time RT-PCR & Jonstrup et al., 2013 [58] \\
IHNV & Real-time RT-PCR & Purcell et al., 2013 [59] \\
IPNV & Conventional RT-PCR & Orpetveit et al., 2010 [60] \\
SAV-2 & Conventional RT-PCR & Hodneland and Endresen, 2006 [61] \\
PRV-3 & Real-time RT-PCR & Adamek et al., 2019 [18] \\
PRV-3 & Conventional RT-PCR & Olsen et al., 2015 [16] \\
T. bryosalmonae & Real-time PCR & Bettge et al., 2009 [62] \\
Salmo trutta-ef1 $\alpha$ & Real-time PCR & Dietrich et al., 2015 [57] \\
\hline
\end{tabular}

\subsection{Parasitological Examination}

The presence of kidney swelling was evaluated as either 0 (not present) or 1 (present). The caudal kidney tissue sample of each fish was fixed in $10 \%$ neutral buffered formalin for the immunohistochemical examination, and in the samples CZ_2072-CZ_2092, additional kidney tissue was fixed in $70 \%$ ethanol for DNA isolation. Samples of the formalin-fixed caudal kidney were examined by immunohistochemistry using the monoclonal anti-Tetracapsuloides bryosalmonae antibody (AquaMAb-P01, Aquatic Diagnostics, Scotland, UK; [63]), with each kidney sample declared as PKD-positive or -negative. For all kidney samples, ten microscopic fields (200× magnification) per slide were randomly selected, the number of parasites per field was manually counted and the mean number of parasites for all ten fields was calculated [64]. Kidney tissues fixed in 70\% ethanol (samples CZ_2072-CZ_2092) or the formalin-fixed paraffin wax-embedded kidney tissues (samples CZ_1964-CZ_1987) were used for molecular detection of the presence of T. bryosalmonae nucleic acid using the real-time PCR assay by Bettge et al. [62]. DNA for these analyses was extracted using the DNeasy Blood and Tissue kit (QIAGEN, Hilden, Germany), following the manufacturer's instructions.

Author Contributions: Conceptualization, M.P. and M.A.; methodology, M.A. and S.R.; validation, L'.P., and D.S.; formal analysis, M.A.; investigation, L'.P., S.R., H.M., I.P., V.S. and E.S.; resources, D.S.; data curation, E.S.; writing —original draft preparation, L'.P.; writing — review and editing, M.A., D.S., I.P. and M.P.; visualization, M.A.; supervision, M.P.; project administration, M.P.; funding acquisition, L.P. and M.P. All authors have read and agree to the published version of the manuscript.

Funding: This work was supported by the Ministry of Agriculture of the Czech Republic MZE-RO0518 and Project PROFISH CZ.02.1.01/0.0/0.0/16_019/0000869 financed by ERDF in the operational program VVV MŠMT.

Acknowledgments: We thank the Moravian Fishing Association members for their help with the on-site sample collection and to Ludmila Faldíková for proof-reading the manuscript. 
Conflicts of Interest: The authors declare no conflict of interest. The funders had no role in the design of the study; in the collection, analyses, or interpretation of data; in the writing of the manuscript, or in the decision to publish the results.

\section{References}

1. Ministry of Agriculture of the Czech Republic. State of the Czech Argiculture. Available online: http: //eagri.cz/public/web/file/648258/Zelena_zprava_2018.pdf (accessed on 27 June 2020).

2. OIE. OIE-Listed Diseases, Infections and Infestations in Force in 2020. Available online: https://www.oie.int/ animal-health-in-the-world/oie-listed-diseases-2020/ (accessed on 27 June 2020).

3. Reichert, M.; Matras, M.; Skall, H.F.; Olesen, N.J.; Kahns, S. Trade practices are main factors involved in the transmission of viral haemorrhagic septicaemia. J. Fish Dis. 2013, 36, 103-114. [CrossRef] [PubMed]

4. European Commission. Animal Disease Notification System (ADNS). Available online: https://ec.europa.eu/ food/animals/animal-diseases/not-system_en (accessed on 27 June 2020).

5. Pojezdal, L'.; Pokorová, D.; Reschová, S.; Palíková, M.; Vícenová, M.; Veselý, T.; Navrátil, S. Diagnostic efficacy of molecular assays for the viral haemorrhagic septicaemia virus isolates from the Czech Republic. Acta Vet. Brno 2017, 86, 207-212. [CrossRef]

6. $\quad$ Kahns, S.; Skall, H.F.; Kaas, R.S.; Korsholm, H.; Bang Jensen, B.; Jonstrup, S.P.; Dodge, M.J.; Einer-Jensen, K.; Stone, D.; Olesen, N.J. European freshwater VHSV genotype Ia isolates divide into two distinct subpopulations. Dis. Aquat. Org. 2012, 99, 23-35. [CrossRef]

7. Gadd, T.; Jakava-Viljanen, M.; Einer-Jensen, K.; Ariel, E.; Koski, P.; Sihvonen, L. Viral haemorrhagic septicaemia virus (VHSV) genotype II isolated from European river lamprey Lampetra fluviatilis in Finland during surveillance from 1999 to 2008. Dis. Aquat. Org. 2010, 88, 189-198. [CrossRef] [PubMed]

8. Knuesel, R.; Segner, H.; Wahli, T. A survey of viral diseases in farmed and feral salmonids in Switzerland. J. Fish Dis. 2003, 26, 167-182. [CrossRef] [PubMed]

9. Skall, H.F.; Olesen, N.J.; Mellergaard, S. Viral haemorrhagic septicaemia virus in marine fish and its implications for fish farming-A review. J. Fish Dis. 2005, 28, 509-529. [CrossRef]

10. Wallace, I.S.; McKay, P.; Murray, A.G. A historical review of the key bacterial and viral pathogens of Scottish wild fish. J. Fish Dis. 2017, 40, 1741-1756. [CrossRef]

11. Elsayed, E.; Faisal, M.; Thomas, M.; Whelan, G.; Batts, W.; Winton, J. Isolation of viral haemorrhagic septicaemia virus from muskellunge, Esox masquinongy (Mitchill), in Lake St Clair, Michigan, USA reveals a new sublineage of the North American genotype. J. Fish Dis. 2006, 29, 611-619. [CrossRef]

12. Ammayappan, A.; Vakharia, V.N. Molecular characterization of the Great Lakes viral hemorrhagic septicemia virus (VHSV) isolate from USA. Virol. J. 2009, 6, 171. [CrossRef]

13. Kurath, G.; Garver, K.A.; Troyer, R.M.; Emmenegger, E.J.; Einer-Jensen, K.; Anderson, E.D. Phylogeography of infectious haematopoietic necrosis virus in North America. J. Gen. Virol. 2003, 84, 803-814. [CrossRef]

14. Rexhepi, A.; Berxholi, K.; Scheinert, P.; Hamidi, A.; Sherifi, K. Study of viral diseases in some freshwater fish in the Republic of Kosovo. Veterinarski Arhiv 2011, 81, 405-413.

15. Bellec, L.; Louboutin, L.; Cabon, J.; Castric, J.; Cozien, J.; Thiery, R.; Morin, T. Molecular evolution and phylogeography of infectious hematopoietic necrosis virus with a focus on its presence in France over the last 30 years. J. Gen. Virol. 2017, 98, 2438-2446. [CrossRef] [PubMed]

16. Olsen, A.B.; Hjortaas, M.; Tengs, T.; Hellberg, H.; Johansen, R. First description of a new disease in rainbow trout (Oncorhynchus mykiss (Walbaum)) similar to Heart and Skeletal Muscle Inflammation (HSMI) and detection of a gene sequence related to Piscine Orthoreovirus (PRV). PLoS ONE 2015, 10, e0131638. [CrossRef] [PubMed]

17. Vendramin, N.; Kannimuthu, D.; Olsen, A.B.; Cuenca, A.; Teige, L.H.; Wessel, O.; Iburg, T.M.; Dahle, M.K.; Rimstad, E.; Olesen, N.J. Piscine orthoreovirus subtype 3 (PRV-3) causes heart inflammation in rainbow trout (Oncorhynchus mykiss). Vet. Res. 2019, 50, 14. [CrossRef]

18. Adamek, M.; Hellmann, J.; Flamm, A.; Teitge, F.; Vendramin, N.; Fey, D.; Risse, K.; Blakey, F.; Rimstad, E.; Steinhagen, D. Detection of piscine orthoreoviruses (PRV-1 and PRV-3) in Atlantic salmon and rainbow trout farmed in Germany. Transbound. Emerg. Dis. 2019, 66, 14-21. [CrossRef]

19. Dhamotharan, K.; Vendramin, N.; Markussen, T.; Wessel, O.; Cuenca, A.; Nyman, I.B.; Olsen, A.B.; Tengs, T.; Krudtaa Dahle, M.; Rimstad, E. Molecular and antigenic characterization of Piscine orthoreovirus (PRV) from rainbow trout (Oncorhynchus mykiss). Viruses 2018, 10, 170. [CrossRef] 
20. Cartagena, J.; Tambley, C.; Sandino, A.M.; Spencer, E.; Tello, M. Detection of piscine orthoreovirus in farmed rainbow trout from Chile. Aquaculture 2018, 493, 79-84. [CrossRef]

21. Kuehn, R.; Stoeckle, B.C.; Young, M.; Popp, L.; Taeubert, J.E.; Pfaffl, M.W.; Geist, J. Identification of a piscine reovirus-related pathogen in proliferative darkening syndrome (PDS) infected brown trout (Salmo trutta fario) using a next-generation technology detection pipeline. PLoS ONE 2018, 13, e0206164. [CrossRef]

22. Lahnsteiner, F.; Haunschmid, R.; Mansour, N. Possible reasons for late summer brown trout (Salmo trutta Linnaeus 1758) mortality in Austrian prealpine river systems. J. Appl. Ichthyol. 2011, 27, 83-93. [CrossRef]

23. Fux, R.; Arndt, D.; Langenmayer, M.C.; Schwaiger, J.; Ferling, H.; Fischer, N.; Indenbirken, D.; Grundhoff, A.; Dolken, L.; Adamek, M.; et al. Piscine Orthoreovirus 3 is not the causative pathogen of Proliferative Darkening Syndrome (PDS) of brown trout (Salmo trutta fario). Viruses 2019, 11, 112. [CrossRef]

24. Arndt, D.; Fux, R.; Blutke, A.; Schwaiger, J.; El-Matbouli, M.; Sutter, G.; Langenmayer, M.C. Proliferative kidney disease and proliferative darkening syndrome are linked with brown trout (Salmo trutta fario) mortalities in the Pre-Alpine Isar River. Pathogens 2019, 8, 177. [CrossRef] [PubMed]

25. Lewisch, E.; Unfer, G.; Pinter, K.; Bechter, T.; El-Matbouli, M. Distribution and prevalence of T. bryosalmonae in Austria: A first survey of trout from rivers with a shrinking population. J. Fish Dis. 2018, 41, 1549-1557. [CrossRef]

26. Hedrick, R.P.; MacConnell, E.; de Kinkelin, P. Proliferative kidney disease of salmonid fish. Annu. Rev. Fish Dis. 1993, 3, 277-290. [CrossRef]

27. Palikova, M.; Papezikova, I.; Markova, Z.; Navratil, S.; Mares, J.; Mares, L.; Vojtek, L.; Hyrsl, P.; Jelinkova, E.; Schmidt-Posthaus, H. Proliferative kidney disease in rainbow trout (Oncorhynchus mykiss) under intensive breeding conditions: Pathogenesis and haematological and immune parameters. Vet. Parasitol. 2017, 238, 5-16. [CrossRef] [PubMed]

28. European Commission. Commission Implementing Decision (EU) 2015/1554 of 11 September 2015 Laying Down Rules for the Application of Directive 2006/88/EC as Regards Requirements for Surveillance and Diagnostic Methods. Available online: http://data.europa.eu/eli/dec_impl/2015/1554/oj (accessed on 27 June 2020).

29. Jørgensen, P.E.V. Egtved virus: The susceptibility of brown trout and rainbow trout to eight virus isolates and the significance of the findings for the VHS control. Fish Dis. 1980, 3-7. [CrossRef]

30. Abbadi, M.; Fusaro, A.; Ceolin, C.; Casarotto, C.; Quartesan, R.; Dalla Pozza, M.; Cattoli, G.; Toffan, A.; Holmes, E.C.; Panzarin, V. Molecular evolution and phylogeography of co-circulating IHNV and VHSV in Italy. Front. Microbiol. 2016, 7, 1306. [CrossRef]

31. Dixon, P.F.; Avery, S.; Chambers, E.; Feist, S.; Mandhar, H.; Parry, L.; Stone, D.M.; Strommen, H.K.; Thurlow, J.K.; Lui, C.T.; et al. Four years of monitoring for viral haemorrhagic septicaemia virus in marine waters around the United Kingdom. Dis. Aquat. Org. 2003, 54, 175-186. [CrossRef]

32. Dopazo, C.P.; Moreno, P.; Olveira, J.G.; Borrego, J.J. The theoretical reliability of PCR-based fish viral diagnostic methods is critically affected when they are applied to fish populations with low prevalence and virus loads. J. Appl. Microbiol. 2018, 124, 977-989. [CrossRef]

33. Fringuelli, E.; Rowley, H.M.; Wilson, J.C.; Hunter, R.; Rodger, H.; Graham, D.A. Phylogenetic analyses and molecular epidemiology of European salmonid alphaviruses (SAV) based on partial E2 and nsP3 gene nucleotide sequences. J. Fish Dis. 2008, 31, 811-823. [CrossRef]

34. State Veterinary Administration. Disease Status of Fish in the Czech Republic. Available online: https: //www.svscr.cz/zdravi-zvirat/zdravi-ryb/nakazova-situace-v-cr/ (accessed on 27 June 2020).

35. Madhun, A.S.; Isachsen, C.H.; Omdal, L.M.; Einen, A.C.B.; Bjorn, P.A.; Nilsen, R.; Karlsbakk, E. Occurrence of Salmonid Alphavirus (SAV) and Piscine Orthoreovirus (PRV) infections in wild sea trout Salmo trutta in Norway. Dis. Aquat. Org. 2016, 120, 109-113. [CrossRef]

36. Vendramin, N.; Alencar, A.L.F.; Iburg, T.M.; Dahle, M.K.; Wessel, O.; Olsen, A.B.; Rimstad, E.; Olesen, N.J. Piscine orthoreovirus infection in Atlantic salmon (Salmo salar) protects against subsequent challenge with infectious hematopoietic necrosis virus (IHNV). Vet. Res. 2018, 49, 30. [CrossRef] [PubMed]

37. Gorgoglione, B.; Taylor, N.G.H.; Holland, J.W.; Feist, S.W.; Secombes, C.J. Immune response modulation upon sequential heterogeneous co-infection with Tetracapsuloides bryosalmonae and VHSV in brown trout (Salmo trutta). Fish Shellfish Immunol. 2019, 88, 375-390. [CrossRef] [PubMed] 
38. Schmidt-Posthaus, H.; Steiner, P.; Muller, B.; Casanova-Nakayama, A. Complex interaction between proliferative kidney disease, water temperature and concurrent nematode infection in brown trout. Dis. Aquat. Org. 2013, 104, 23-34. [CrossRef] [PubMed]

39. Clifton-Hadley, R.S.; Bucke, D.; Richards, R.H. Proliferative kidney disease of salmonid fish: A review. J. Fish Dis. 1984, 7, 363-377. [CrossRef]

40. Grabner, D.S.; El-Matbouli, M. Comparison of the susceptibility of brown trout (Salmo trutta) and four rainbow trout (Oncorhynchus mykiss) strains to the myxozoan Tetracapsuloides bryosalmonae, the causative agent of proliferative kidney disease (PKD). Vet. Parasitol. 2009, 165, 200-206. [CrossRef] [PubMed]

41. Wahli, T.; Knuesel, R.; Bernet, D.; Segner, H.; Pugovkin, D.; Burkhardt-Holm, P.; Escher, M.; Schmidt-Posthaus, H. Proliferative kidney disease in Switzerland: Current state of knowledge. J. Fish Dis. 2002, 25, 491-500. [CrossRef]

42. Wahli, T.; Bernet, D.; Steiner, P.A.; Schmidt-Posthaus, H. Geographic distribution of Tetracapsuloides bryosalmonae infected fish in Swiss rivers: An update. Aquat. Sci. 2007, 69, 3-10. [CrossRef]

43. Rubin, A.; de Coulon, P.; Bailey, C.; Segner, H.; Wahli, T.; Rubin, J.F. Keeping an eye on wild brown trout (Salmo trutta) populations: Correlation between temperature, environmental parameters, and proliferative kidney disease. Front. Vet. Sci. 2019, 6, 281. [CrossRef]

44. Peeler, E.J.; Feist, S.W.; Longshaw, M.; Thrush, M.A.; St-Hilaire, S. An assessment of the variation in the prevalence of renal myxosporidiosis and hepatitis in wild brown trout, Salmo trutta L.; within and between rivers in South-West England. J. Fish Dis. 2008, 31, 719-728. [CrossRef]

45. Dash, M.; Vasemagi, A. Proliferative kidney disease (PKD) agent Tetracapsuloides bryosalmonae in brown trout populations in Estonia. Dis. Aquat. Org. 2014, 109, 139-148. [CrossRef]

46. Abd-Elfattah, A.; Kumar, G.; Soliman, H.; El-Matbouli, M. Persistence of Tetracapsuloides bryosalmonae (Myxozoa) in chronically infected brown trout Salmo trutta. Dis. Aquat. Org. 2014, 111, 41-49. [CrossRef] [PubMed]

47. Soliman, H.; Kumar, G.; El-Matbouli, M. Tetracapsuloides bryosalmonae persists in brown trout Salmo trutta for five years post exposure. Dis. Aquat. Org. 2018, 127, 151-156. [CrossRef] [PubMed]

48. Kumar, G.; Sarker, S.; Menanteau-Ledouble, S.; El-Matbouli, M. Tetracapsuloides bryosalmonae infection affects the expression of genes involved in cellular signal transduction and iron metabolism in the kidney of the brown trout Salmo trutta. Parasitol. Res. 2015, 114, 2301-2308. [CrossRef] [PubMed]

49. Bailey, C.; Strepparava, N.; Wahli, T.; Segner, H. Exploring the immune response, tolerance and resistance in proliferative kidney disease of salmonids. Dev. Comp. Immunol. 2019, 90, 165-175. [CrossRef] [PubMed]

50. Borsuk, M.E.; Reichert, P.; Peter, A.; Schager, E.; Burkhardt-Holm, P. Assessing the decline of brown trout (Salmo trutta) in Swiss rivers using a Bayesian probability network. Ecol. Model. 2006, 192, 224-244. [CrossRef]

51. Schmidt-Posthaus, H.; Bernet, D.; Wahli, T.; Burkhardt-Holm, P. Morphological organ alterations and infectious diseases in brown trout Salmo trutta and rainbow trout Oncorhynchus mykiss exposed to polluted river water. Dis. Aquat. Org. 2001, 44, 161-170. [CrossRef]

52. Zimmerli, S.; Bernet, D.; Burkhardt-Holm, P.; Schmidt-Posthaus, H.; Vonlanthen, P.; Wahli, T.; Segner, H. Assessment of fish health status in four Swiss rivers showing a decline of brown trout catches. Aquat. Sci. 2007, 69, 11-25. [CrossRef]

53. Wahli, T.; Bernet, D.; Segner, H.; Schmidt-Posthaus, H. Role of altitude and water temperature as regulating factors for the geographical distribution ofTetracapsuloides bryosalmonaeinfected fishes in Switzerland. J. Fish Biol. 2008, 73, 2184-2197. [CrossRef]

54. Cinkova, K.; Reschová, S.; Kulich, P.; Veselý, T. Evaluation of a polyclonal antibody for the detection and identification of ranaviruses from freshwater fish and amphibians. Dis. Aquat. Org. 2010, 89, 191-198. [CrossRef]

55. Farr, A.G.; Nakane, P.K. Immunohistochemistry with enzyme labeled antibodies: A brief review. J. Immunol. Methods 1981, 47, 129-144. [CrossRef]

56. Dereeper, A.; Guignon, V.; Blanc, G.; Audic, S.; Buffet, S.; Chevenet, F.; Dufayard, J.F.; Guindon, S.; Lefort, V.; Lescot, M.; et al. Phylogeny.fr: Robust phylogenetic analysis for the non-specialist. Nucleic Acids Res. 2008, 36, 465-469. [CrossRef] [PubMed]

57. Dietrich, M.A.; Nynca, J.; Adamek, M.; Steinhagen, D.; Karol, H.; Ciereszko, A. Expression of apolipoprotein A-I and A-II in rainbow trout reproductive tract and their possible role in antibacterial defence. Fish Shellfish Immunol. 2015, 45, 750-756. [CrossRef] [PubMed] 
58. Jonstrup, S.P.; Kahns, S.; Skall, H.F.; Boutrup, T.S.; Olesen, N.J. Development and validation of a novel Taqman-based real-time RT-PCR assay suitable for demonstrating freedom from viral haemorrhagic septicaemia virus. J. Fish Dis. 2013, 36, 9-23. [CrossRef]

59. Purcell, M.K.; Thompson, R.L.; Garver, K.A.; Hawley, L.M.; Batts, W.N.; Sprague, L.; Sampson, C.; Winton, J.R. Universal reverse-transcriptase real-time PCR for infectious hematopoietic necrosis virus (IHNV). Dis. Aquat. Org. 2013, 106, 103-115. [CrossRef] [PubMed]

60. Orpetveit, I.; Mikalsen, A.B.; Sindre, H.; Evensen, O.; Dannevig, B.H.; Midtlyng, P.J. Detection of infectious pancreatic necrosis virus in subclinically infected Atlantic salmon by virus isolation in cell culture or real-time reverse transcription polymerase chain reaction: Influence of sample preservation and storage. J. Vet. Diagn. Investig. 2010, 22, 886-895. [CrossRef] [PubMed]

61. Hodneland, K.; Endresen, C. Sensitive and specific detection of Salmonid alphavirus using real-time PCR (TaqMan). J. Virol. Methods 2006, 131, 184-192. [CrossRef] [PubMed]

62. Bettge, K.; Segner, H.; Burki, R.; Schmidt-Posthaus, H.; Wahli, T. Proliferative kidney disease (PKD) of rainbow trout: Temperature- and time-related changes of Tetracapsuloides bryosalmonae DNA in the kidney. Parasitology 2009, 136, 615-625. [CrossRef]

63. Adams, A.; Richards, R.H.; Mateo, M.M. Development of monoclonal antibodies to $\mathrm{PK}^{\prime} \mathrm{X}^{\prime}$, the causative agent of proliferative kidney disease. J. Fish Dis. 1992, 15, 515-521. [CrossRef]

64. Schmidt-Posthaus, H.; Bettge, K.; Forster, U.; Segner, H.; Wahli, T. Kidney pathology and parasite intensity in rainbow trout Oncorhynchus mykiss surviving proliferative kidney disease: Time course and influence of temperature. Dis. Aquat. Org. 2012, 97, 207-218. [CrossRef]

(C) 2020 by the authors. Licensee MDPI, Basel, Switzerland. This article is an open access article distributed under the terms and conditions of the Creative Commons Attribution (CC BY) license (http://creativecommons.org/licenses/by/4.0/). 